\title{
Climatically induced changes in late Quaternary bathyal ostracod assemblages of the Camamu Basin, Brazil
}

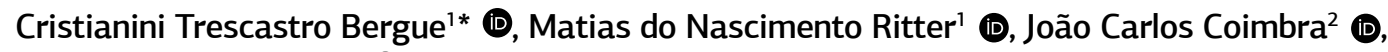 \\ Karen Badaraco $\operatorname{Costa}^{3}$ (1)
}

\begin{abstract}
Bathybic ostracods (i.e., bathyal and abyssal assemblages) are important indicators of temperature and productivity changes of Cenozoic marine ecosystems. The present work presents the first study on Quaternary ostracods of the Camamu Basin, off the state of Bahia, northeastern Brazilian continental margin. The analysis of 59 samples from the piston-core CMU 14 ( $14^{\circ} 24^{\prime} \mathrm{S}, 38^{\circ} 49^{\prime} \mathrm{W}$; $965 \mathrm{~m}$ water depth), revealed rich and abundant assemblages. The ${ }^{14} \mathrm{C}$ accelerator mass spectrometry (AMS) dating indicates that the studied interval covers the last $108 \mathrm{kyr}$, corresponding to the oxygen stable isotope stages (MIS) 5 to 1. Comparison with data from previous publications allowed discernment of three groups of ostracod species in CMU 14: Pandemic Group of species registered in more than one oceanic basin; Atlantic/Mediterranean Group of species restricted to the Atlantic Ocean and Mediterranean; and Brazilian Group of species restricted to the Brazilian continental margin). Four new species are herein proposed: Cytherella pindoramensis sp. nov., Ambocythere amadoi sp. nov., Pseudobosquetina pucketti sp. nov., and Bythoceratina bonaterrae sp. nov. Ostracod occurrences reveal the influence of glacial/interglacial cycles on assemblages composition. Interglacial stages 5 and 1 in the Camamu Basin are characterized by the association Bythocypris affinis-Cytherella pindoramensis sp. nov.Cytheropteron perlaria-Bradleya dictyon; glacial stages (i.e., 2 to 4) register decreased diversity, possibly due to lower oceanic productivity.
\end{abstract}

KEYWORDS: paleoceanography; bathybic faunas; Atlantic Ocean; paleoproductivity; ostracod taxonomy.

\section{INTRODUCTION}

Research over the past 50 years has supplied invaluable data for the understanding of ostracod assemblages from deep oceanic regions (Benson 1975, Cronin 1983, Benson et al. 1984, Whatley and Coles (1991), Majoran and Dingle 2002, Cronin and Dwyer 2003, Yasuhara and Cronin 2008, Yasuhara et al. 2014 , inter alia). Those studies revealed not only the bathymetric distributional pattern, but also changes in assemblage composition along glacial, deglacial and interglacial stages, especially in response to variations of the oxygen minimum zone (OMZ) depth, and oceanic productivity.

In spite of its potentiality, the research on bathybic ostracods in Brazil is mostly limited to a few bathyal regions of the Brazilian Continental Margin (BCM), more precisely the Pelotas, Santos and Campos basins (i.e. $21-35^{\circ} \mathrm{S}$ ) (Carreño et al. 1999, Drozinski et al. 2003, Bergue et al. 2006, 2007, 2017, Bergue and Coimbra 2008, Sousa et al. 2013, Maia et al. 2021). A northward expansion of this research is imperative

${ }^{1}$ Centro de Estudos Costeiros, Limnológicos e Marinhos, Departamento Interdisciplinar, Universidade Federal do Rio Grande do Sul - Imbé (RS), Brazil. E-mails: ctbergue@gmail.com, matias.ritter@ufrgs.br

${ }^{2}$ Departamento de Paleontologia e Estratigrafia, Universidade Federal do Rio Grande do Sul - Porto Alegre (RS), Brazil. E-mail: joao.coimbra@ufrgs.br

${ }^{3}$ Praça do Oceanográfico, Departamento de Oceanografia Física, Química e Geológica, Instituto Oceanográfico, Universidade de São Paulo - São Paulo (SP), Brazil. E-mail: karen.costa@usp.br

${ }^{*}$ Corresponding author.

(C) 2021 The authors. This is an open access article distributed under the terms of the Creative Commons license. to broaden our understanding on the parameters influencing species occurrence in different basins scenarios. The main purpose of this paper was to extend the research into the northeastern Brazilian margin. To accomplish this goal, we studied a site in the Camamu Basin (off Bahia State) and discussed the geographic and stratigraphic occurrences of some species registered therein.

The Camamu Basin lies in the northeastern sector of the BCM (Martins and Coutinho 1981) between $13^{\circ}$ and $14^{\circ} \mathrm{S}$, and it registers deposits ranging from the Jurassic to the Quaternary in age (Fig. 1). It is limited to the north by the Recôncavo and Jacuípe

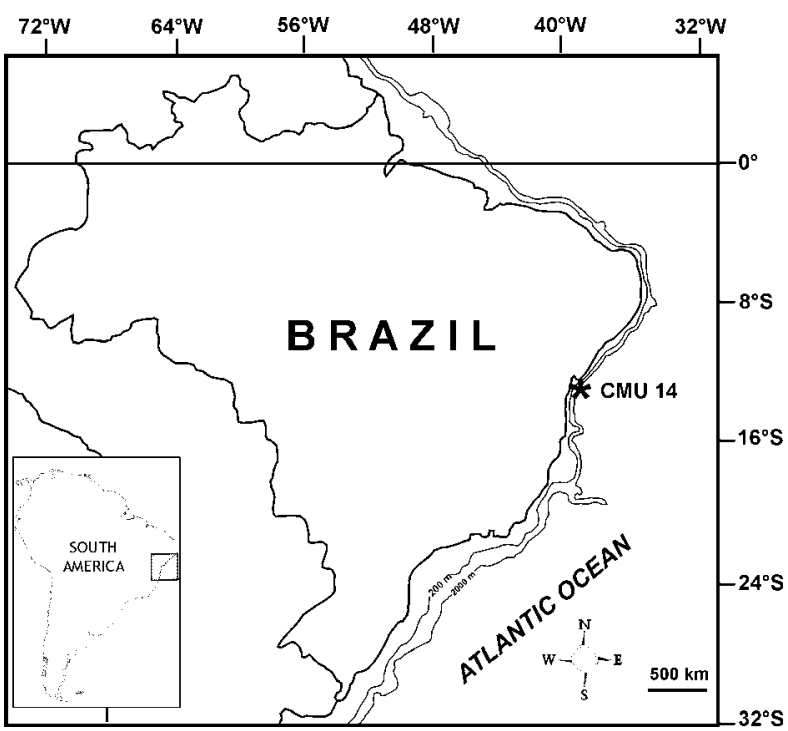

Figure 1. Study area with location of the core CMU 14 in the in the BCM. 
basins, and to the south by the Almada Basin. The Quaternary sediments studied herein correspond to the sequence N60, which is predominantly composed of clay (Caixeta et al.2007). The Camamu Basin is in the narrowest sector of the BCM, whose bathyal portion is bathed by the Antarctic Intermediate Water (AAIW) (Stramma and England 1999).

\section{MATERIAL AND METHODS}

The piston-core CMU 14 (4.56 m length), obtained in the continental slope of the Camamu Basin (14²4'S; $38^{\circ} 49^{\prime} \mathrm{W}$ ) at $965 \mathrm{~m}$ water depth, was sampled approximately each six centimeters, yielding 59 samples. Preparation involved washing through a $0.062 \mathrm{~mm}$ sieve, followed by oven-drying at $60^{\circ} \mathrm{C}$. All specimens from the samples were picked out and stored in micropaleontological slides for taxonomic analysis. Representative specimens (either valves or carapaces) of each species were selected for SEM at Centro de Microscopia e Microanálise, Universidade Federal do Rio Grande do Sul.

The sedimentation rate at this site was approximately $6.5 \mathrm{~cm} / \mathrm{kyr}$ during the Last Glacial Maximum (LGM) and deglacial, and $\sim 3 \mathrm{~cm} / \mathrm{kyr}$ during the Holocene (Toledo et al. 2007). The ${ }^{14} \mathrm{C}$ accelerator mass spectrometry (AMS) dating - carried out at NOS AMS-WHOI laboratory, and corrected for a reservoir effect of $400 \mathrm{yr}$ (Bard 1988) — indicates that the studied interval covers the last $108 \mathrm{kyr}$ (i.e., marine isotope stages - MIS, 5 to 1 ).

The Shannon index was calculated for diversity assessment along the core. This metric is an entropy estimate that includes the relative abundance of taxa (Shannon 1948). In this paper, the term "fauna" refers to taxa that lived during a certain interval of time, either in the local or global sense; "assemblage" refers to a group of fossil specimens present in a sample (both autochthonous [within-habitat time-averaged] and allochthonous [out-of-habitat]), and "association" is a group of taxa that lived together and characterize an ecological scenario (also called census). The material herein studied is held at the Museu de Paleontologia Irajá Damiani Pinto, Universidade Federal do Rio Grande do Sul, Porto Alegre, Brazil.

\section{RESULTS}

\section{Assemblage composition}

Taxonomic analysis of the assemblages recovered from the core CMU 14 allowed the identification of 40 taxa, four of which proposed as new species (Figs. 2 and 3). In zoogeographic terms, these species are divided into three groups, as follows:

- Pandemic Group, composed of species registered in several deep-sea regions worldwide;

- Atlantic/Mediterranean Group, composed of species restricted to the Atlantic Ocean and Mediterranean;

- Brazilian Group, whose species are restricted to the BCM.

Examples of the Pandemic Group are Jonesia cuneata Schornikhov 1981, Bythoceratina scaberrima (Brady 1886), and Cytheropteron perlaria Hao 1988 all registered in the Atlantic,
Indian, and Pacific oceans. The Atlantic/Mediterranean Group includes Bythopussella brandtae Brandão 2008, Bythocypris affinis Brady 1880, and Saida ionia Ciampo 1988. Lastly, the Brazilian Group is represented by Cytherella santosensis Bergue et al. 2007, Microcythere dubia (Bergue and Coimbra 2008) and Microcythere acuminata Bergue et al. 2019, for instance. The four new species herein described probably belong to this group, but only additional studies will allow this hypothesis to be tested.

\section{Taxonomic descriptions (by C.T. Bergue \& J.C. Coimbra)}

The suprageneric taxonomy used herein mainly follows Liebau (2005). Morphological abbreviations: H, height; L, length; W, width; C, carapace; RV, right valve; LV, left valve; AMS, adductor muscle scars; MIS, marine isotope stage.

Subclass OSTRACODA Latreille 1802

Superorder PODOCOPOMORPHA Kozur 1972

Order PLATYCOPIDA Sars 1866

Superfamily CYTHERELLOIDEA Sars 1866

Family CYTHERELLIDAE Sars 1866

Cytherella Jones 1849

Cytherella pindoramensis sp. nov.

(Figs. 2B-2F)

Etymology. From the Tupy language pindorama (= the land of palm trees), a designation formerly given to Brazil by native people.

Zoobank register. act:65791522-F7EF-4A3C-9AFF-1CE913C13D45.

Holotype. MP-O-2950, LV, L $=1.35 \mathrm{~mm}, \mathrm{H}=0.83 \mathrm{~mm}$ (Sample $377 \mathrm{~cm}$, Pleistocene).

Paratypes. MP-O-2951, RV, L $=1.4 \mathrm{~mm}, \mathrm{H}=0.92 \mathrm{~mm}$ (Sample $199 \mathrm{~cm}$, Pleistocene); MP-O-2952, RV, L = $1.4 \mathrm{~mm}$, $\mathrm{H}=0.90 \mathrm{~mm}$ (Sample $456 \mathrm{~cm}$, Pleistocene); MP-O-2953, LV, $\mathrm{L}=1.35 \mathrm{~mm}, \mathrm{H}=0.93 \mathrm{~mm}$ (Sample $178 \mathrm{~cm}$, Pleistocene); MP-O-2954, juvenile RV, L $=0.76 \mathrm{~mm}, \mathrm{H}=0.55 \mathrm{~mm}$ (Sample $43 \mathrm{~cm}$, Holocene); MP-O-2955, juvenile LV, L $=0.73 \mathrm{~mm}, \mathrm{H}$ $=0.50 \mathrm{~mm}$ (Sample $43 \mathrm{~cm}$, Holocene).

Type-locality and horizon. Camamu Basin (Brazil), piston-core CMU 14 (14²4’S; 3849'12”W). Pleistocene.

Occurrence and abundance. MIS 5, 3, and 1. Samples: 0 $\mathrm{cm}(1 \mathrm{v}), 12 \mathrm{~cm}(1 \mathrm{v}), 43 \mathrm{~cm}(1 \mathrm{c}), 54 \mathrm{~cm}(1 \mathrm{v}), 167 \mathrm{~cm}(1 \mathrm{v})$, $190 \mathrm{~cm}(1 \mathrm{v}), 199 \mathrm{~cm}(2 \mathrm{v}), 260 \mathrm{~cm}(1 \mathrm{v}), 278 \mathrm{~cm}(1 \mathrm{v}), 377 \mathrm{~cm}$ (1v), and $456 \mathrm{~cm}(1 \mathrm{v})$.

Stratigraphical and geographical distribution. Known only in the type-locality.

Diagnosis. A giant and smooth species of Cytherella. $\mathrm{RV}$ much more ovate than LV, overlapping it mainly dorsally and ventrally. A narrow and delicately corrugated rim adorns the LV free margin. A group of two rows with 25 AMS stands out close to the center, just above mid-height.

Description. Very large C. RV overlapping LV along all margins, more conspicuously in the dorsal and ventral ones. Greatest length at mid-height; greatest width in the middle; greatest height median in LV, immediately before the middle in RV. LV subovate to subrectangular in lateral view. Anterior 


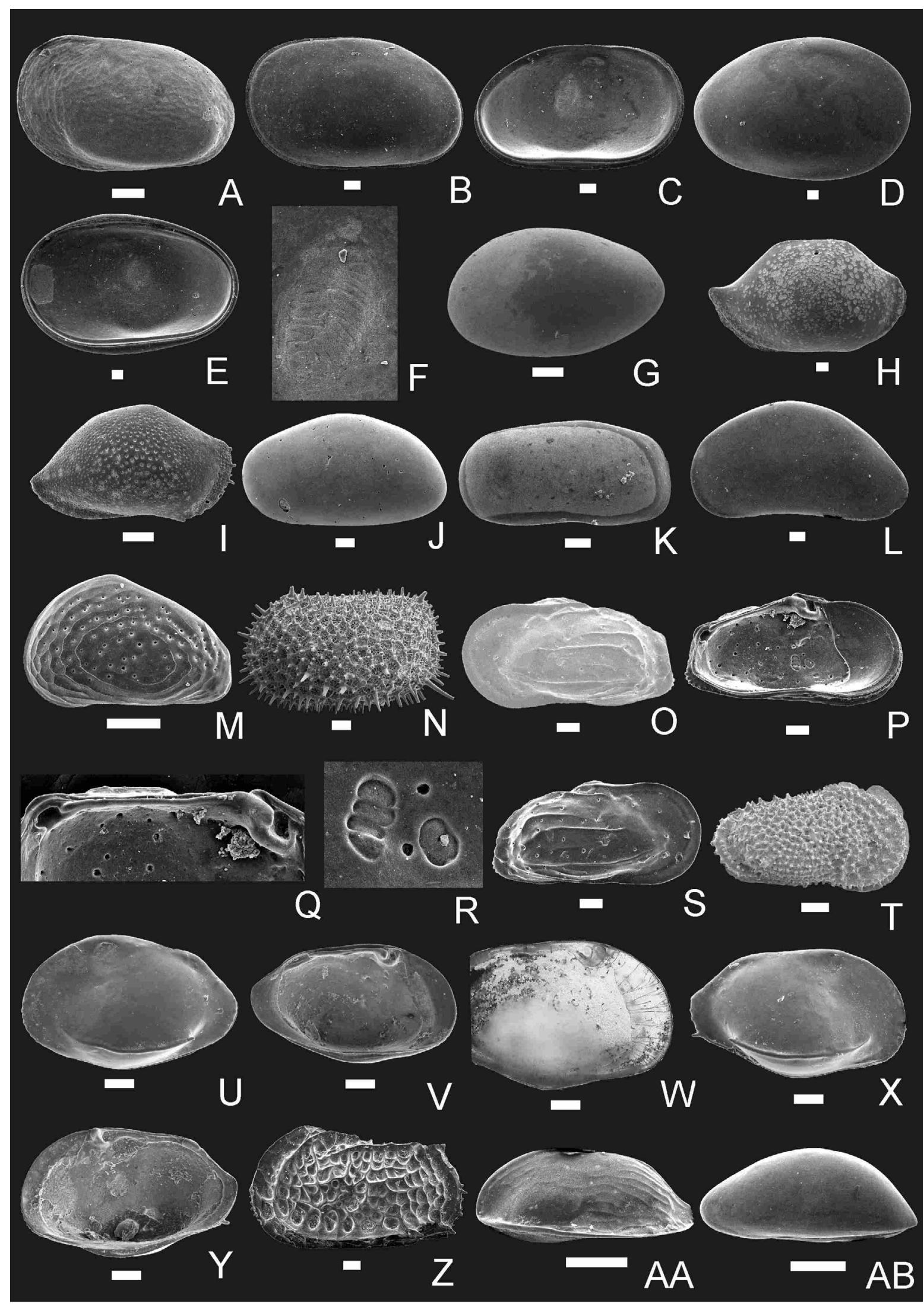

Figure 2. (A) Cytherella santosensis Bergue et al. 2007, juvenile LV, MP-O-2949; (B-F), Cytherella pindoramensis sp. nov. B, LV, holotype, MP-O-2950; (C), holotype internal view; (D), RV, paratype, MP-O-2951; (E) paratype internal view, MP-O-2951; (F) detail of the AMS of the holotype; (G) Cardobairdia bensoni (Maddocks 1972), LV, MP-O-2956; (H) Bairdia sp. aff. B. hirsuta Brady (1880), RV, MP-O-2957; (I) Bythopussella brandtae Brandão 2008, RV, MP-O-2958; (J) Bythocypris affinis (Brady 1886), male LV, MP-O-2959; (K) Bythocypris sp., RV, MP-O-2960; (L) Zabythocypris sp., LV, MP-O-2961; (M) Eucythere circumcostata Whatley and Coles 1987, LV, MP-O2962; (N) Marwickcythereis ericea (Brady 1880), LV, MP-O-2963; (O-S) Ambocythere amadoi sp. nov.; (O) LV, holotype, MP-O-2964; (P) holotype internal view; (Q) detail of the holotype hinge; (R) detail of the holotype central muscle scars; (S) RV, paratype, MP-O-2965; (T) Rugocythereis horrida Whatley and Coles 1987, male RV, MP-O-2968; (U-Y) Pseudobosquetina pucketti sp. nov.; (U) LV, MP-O-2969, holotype; (V) holotype internal view; (W) details of the holotype CMS and RPC (optical microscopy); (X) RV, paratype, MP-O-2970; (Y) paratype internal view, MP-O-2970; (Z) Bradleya dictyon (Brady 1880), RV, MP-O-2974; (AA) Microcythere dubia (Bergue and Coimbra 2008), LV, MP-O-2975; (AB) Microcythere acuminata Bergue et al. 2019, LV, MP-O-2976. 


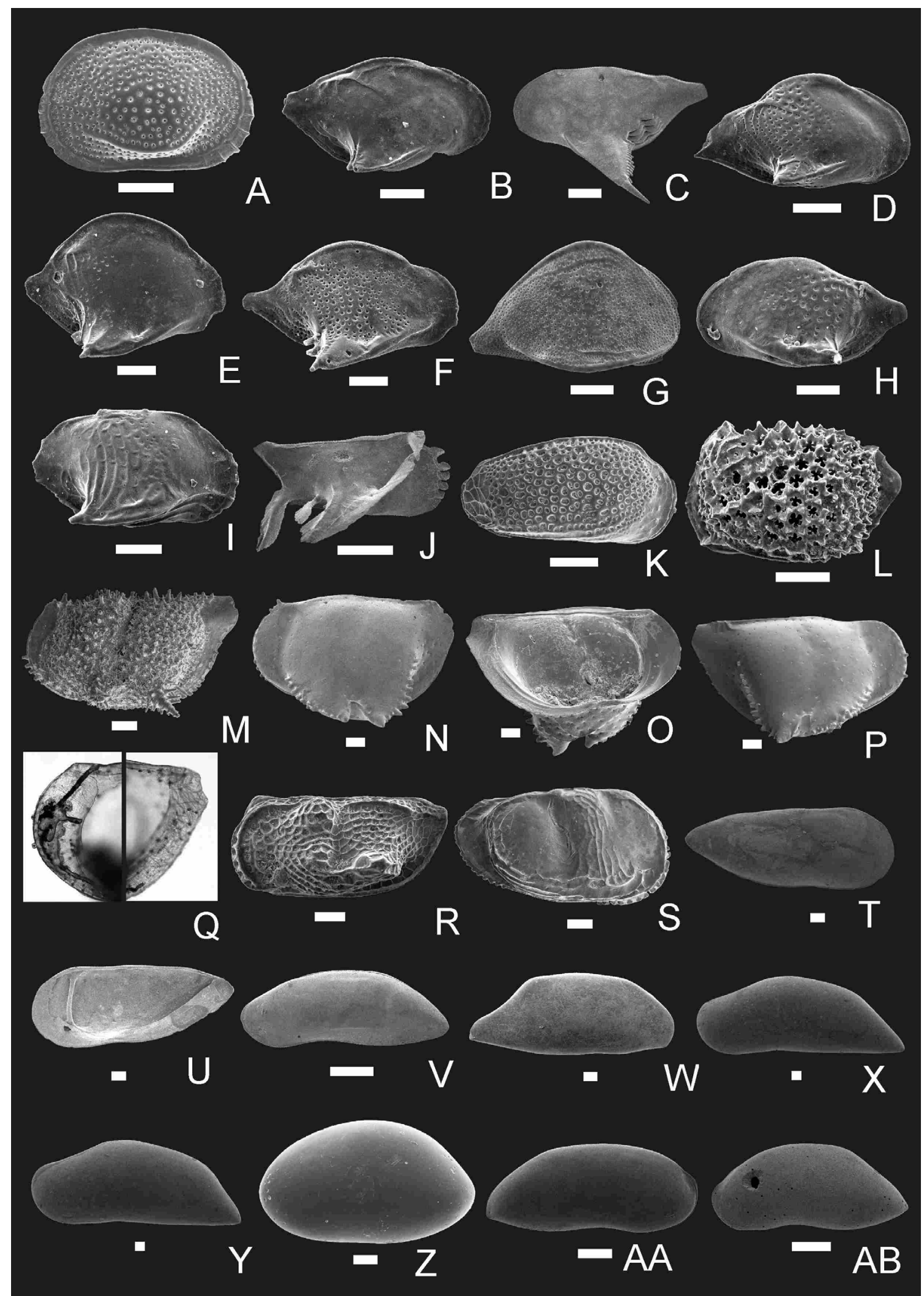

Figure 3. (A) Saida ionia Ciampo 1988, LV, MP-O-2977; (B) Cytheropteron inornatum Brady and Robertson 1872, RV, MP-O-2976; (C) Cytheropteron pherozigzag Whatley et al. 1986, LV, MP-O-2979; (D) Cytheropteron massoni Whatley and Coles 1987, RV, MP-O-2980; (E) Cytheropteron lineoporosa Whatley and Coles 1987, RV, MP-O-2981; (F) Cytheropteron carolinae Whatley and Coles 1987, RV, MP-O-2982; (G) Cytheropteron perlaria Hao 1988, RV, MP-O-2983; (H) Cytheropteron demenocali Yasuhara et al. 2009c, LV, MP-O-2984; (I) Aversovalva hydrodynamica Whatley and Coles 1987 RV, MP-O-2985; (J) Pedicythere lachesisopetasi Yasuhara et al. 2009c, RV, MP-O-2986; (K) Xylocythere turnerae Maddocks and Steineck 1987 RV, MP-O-2987; (L) Eucytherura sp. cf. E. calabra Colalongo and Pasini 1980 LV, MP-O-2988; (M) Bythoceratina scaberrima (Brady 1866), LV, MP-O-2989; (N-Q) Bythoceratina bonaterrae sp. nov.; (N) broken LV, holotype, MP-O-2990; (O) holotype internal view; (P) RV, paratype, MP-O-2992; (Q) detail of the anterior and posterior margins showing the radial porecanals (in optical microscopy); (R) Bythoceratina sp., RV, MP-O-2994; (S) Bythocythere eugenischornikovi, RV, MP-O-2995; (T-U) Jonesia cuneata Schornikhov 1981; (T) RV, MP-O-2996; (U) same specimen internal view; (V) Paracytherois antarctica Hartmann 1992, LV, MP-O-2997; (W) Macrosarissa bensoni Maddocks 1990, RV, MP-O-2998; (X) Macropyxis cronini Brandão 2010 LV, MP-O-2999; (Y) Macropyxis alanlordi Brandão 2010, LV, MP-O-3000; (Z) Australoecia sp. cf. A. tipica van den Bold 1974, LV, MP-O-3001; (AA) Argilloecia acuminata Müller 1894, RV, MP-O-3002; (AB) Argilloecia labri Yasuhara and Okahashi 2015, LV, MP-O-3003. 
margin asymmetrically rounded, more protruded in the upper half. Posterior margin narrowly and asymmetrically rounded, more protruded in the lower half. Dorsal margin slightly convex, sloping posteriorly. Ventral margin with a gentle oral concavity hidden by somewhat convex outline. RV subovate in lateral view. Anterior margin more broadly rounded than in LV, but also asymmetric and more protruded dorsally. Posterior margin similar to the LV. Dorsal and ventral margins hidden by the strongly convex outline. Smooth valve surface. $L V$ with a narrow and delicately corrugated rim along the free margin. Internally, a well-developed selvage-like structure runs along all margins, fitting into a groove in the complementary valve. AMS placed near the center, immediately above middle height, on a subtle internal elevation, being composed of about 25 individual marks grouped into two rows. Above these, a small group of scars lies near the dorsal margin. Sexual dimorphism not observed.

Remarks. Swanson et al. (2005) proposed the genus Inversacytherella to accommodate cytherellids with a reverse overlap pattern (i.e., LV > RV) and unusual AMS composed of over 20 individual scars. Fossil Inversacytherella species were registered in Brazil by Bergue et al. $(2007,2019)$ and Manica et al. (2015). Although AMS of Cytherella pindoramensis sp. nov. are composed of over 20 scars, the RV is larger than the LV, i.e., the species herein proposed have diagnostic characters of both Cytherella and Inversacytherella. Following a more conservative approach, we opted to describe this species in the genus Cytherella. Cytherella pindoramensis sp. nov. differs from most species of the genus recorded in the BCM in having the surface totally smooth. It is somewhat similar to Inversacytherella pleistocenica (Bergue et al. 2007, Manica et al. 2015), but the latter has more subelliptical LV outline and LV larger than RV. Cytherella pindoramensis sp. nov. occurs only in interglacial stages in the piston-core CMU 14.

\section{Order PODOCOPIDA Sars 1866}

Family TRACHYLEBERIDIDAE Sylvester-Bradley 1948

Ambocythere van den Bold 1957

Ambocythere amadoi sp. nov.

(Figs. 2O-2S)

Etymology. In honor of the Brazilian writer Jorge Amado (1912-2001), born in Bahia State, on whose coast lies the Camamu Basin.

Zoobank register. act:08771EE1-081B-458D-B841-C62B64748D35.

Holotype. MP-O-2964, LV, L $=0.65 \mathrm{~mm}, \mathrm{H}=0.30 \mathrm{~mm}$ (sample $359 \mathrm{~cm}$ ).

Paratypes. MP-O-2965, LV, L $=0.63 \mathrm{~mm}, \mathrm{H}=0.30 \mathrm{~mm}$ (sample $238 \mathrm{~cm}$ ); MP-O-2966, C, L $=0.55 \mathrm{~mm}, \mathrm{H}=0.35$ $\mathrm{mm}, \mathrm{W}=0.27 \mathrm{~mm}$ (sample $260 \mathrm{~cm}$ ); MP-O-2967, LV, L = $0.56 \mathrm{~mm}, \mathrm{H}=0.33 \mathrm{~mm}$ (sample $260 \mathrm{~cm}$ ).

Type-locality and horizon. Camamu Basin (Brazil), core CMU 14 (14²4'S; 3849'W). Pleistocene.

Occurrence and abundance. MIS 5-2. Samples: $144 \mathrm{~cm}$ (1v), $238 \mathrm{~cm}(1 \mathrm{v}), 260 \mathrm{~cm}(3 \mathrm{v}), 283 \mathrm{~cm}(2 \mathrm{v}), 289 \mathrm{~cm}(2 \mathrm{v})$, 359 (1v), and $438 \mathrm{~cm}$ (1v).

Stratigraphical and geographical distribution. Known only in the type-locality. Pleistocene.
Diagnosis. A medium and thick-shelled species of Ambocythere without a typical caudal process. Dorsal margin with a conspicuous dome-like anterior cardinal angle. Few longitudinal ribs whose length decreases from the ventral to the dorsal region, ornate the last two thirds of each valve. Three delicate rounded spines developed posteroventrally.

Description. Medium carapace, thick shelled, subrectangular in lateral view. Greatest length at mid-height; greatest height in the first third; greatest width posteriorly. Dorsal margin well marked by the anterior cardinal angle, situated roughly at mid-length of each valve. Ventral margin sinuous, slightly obscured by a ventral carina mainly in RV, and with oral concavity at mid-length. Anterior margin supracurvate bordered by a carina running from the base of the dome formed at the anterior cardinal angle, up to the mid-ventral. Posterior margin obliquely truncate, ventrally ornamented by three delicate rounded spines. Surface predominantly smooth at the anterior third; median and posterior parts marked by few longitudinal ribs whose length decreases from the ventral toward the dorsal ones. A gentle dorsal rib runs sinuously along the posterior half. Large normal pore-canals scattered along the surface, more numerous in the posterior half. Internally, very wide anterior duplicature with a sinuous inner margin; posterior one relatively narrow. Central muscle scars typical for the genus, placed at the lower half and marked by two normal porecanals between the AMS and frontal scar. Hinge holamphidont quite robust compared to other species of the genus. LV anterior element, a deep subtriangular socket completely closed. Anterior tooth elongated and projected forward, followed by a thick smooth bar slightly enlarged posteriorly. Posterior socket deep, subelliptical, and open. Marginal porecanals numerous, some branched near the anterior margin. Sexual dimorphism not seen.

Remarks. Ambocythere amadoi sp. nov. belongs to a group of species of the genus with a non-projected posterior margin. It differs from A. hyakunome Yasuhara et al. 2015, described in the northwestern Atlantic, mainly in the outline of the posterior margin, surface features, and robustness of hinge elements. From A circumporus Bergue et al. 2017 differs mostly in having a more subrectangular outline, a less ornate surface, and absence of a typical caudal process.

\section{Pseudobosquetina Guernet and Moulade 1994}

Remarks. The authors are aware of the debate about the validity of the genus Pseudobosquetina, mainly about its synonymization (or not) with the oldest genus Pterygocythere Hill 1954. Ayress et al. (2004) and Yasuhara et al. (2015), although they did not elaborate on this subject, considered Pseudobosquetina as a junior synonym of Pterygocythere. Conversely, Jellinek et al. (2006, and bibliography therein) not only thoroughly discussed the similarities and differences of Pseudobosquetina with several other genera, but also ratified P. mucronulata (Brady 1880) as its type species. In addition, they described in detail two new species for this genus, which is still poorly diversified. 
Pseudobosquetina pucketti sp. nov.

(Figs. 2U-2Y)

Etymology. In honor of Terry Markham Puckett for his contribution to the taxonomy and paleozoogeography of Brachycytherinae.

Zoobank register. act:2E388EA5-B88D-4701-92D6-14124A90FDA5.

Holotype. MP-O-2969, LV, L $=0.70 \mathrm{~mm}, \mathrm{H}=0.45 \mathrm{~mm}$ (sample $167 \mathrm{~cm}$ ).

Paratypes. MP-O-2970, LV, L $=0.80 \mathrm{~mm}, \mathrm{H}=0.50 \mathrm{~mm}$ (sample $377 \mathrm{~cm}$ ); MP-O-2971, LV, L = $0.70 \mathrm{~mm}, \mathrm{H}=0.47$ mm (sample $199 \mathrm{~cm}$ ), MP-O-2972, RV, L = $0.68 \mathrm{~mm}, \mathrm{H}=$ $0.40 \mathrm{~mm}$ (sample $167 \mathrm{~cm}$ ); MP-O-2973, LV, L = $0.70 \mathrm{~mm}$, $\mathrm{H}=0.45 \mathrm{~mm}$ (sample $278 \mathrm{~cm}$ ).

Type-locality and horizon. Camamu Basin (Brazil), core CMU 14 (14²4'S; 3849’W). Pleistocene.

Occurrence and abundance. MIS 5 and 3. Samples: $167 \mathrm{~cm}$ (2v), $199 \mathrm{~cm}(2 \mathrm{v}), 278 \mathrm{~cm}(2 \mathrm{v}), 371 \mathrm{~cm}(1 \mathrm{v})$, and $377 \mathrm{~cm}(1 \mathrm{v})$.

Stratigraphical and geographical distribution. Known only in the type-locality.

Diagnosis. Carapace small, very inflated in the middle, and depressed in the anterior and posterior regions. Surface predominantly smooth, except for a feeble but conspicuous ventrolateral rib with short backwardly projected spine. LV without a dorsal plicated area. Anterior duplicature with mostly branched radial porecanals.

Description. Carapace small, strongly calcified, laterally depressed, and quite inflated medianly. Greatest length at midheight; greatest height and greatest width near the middle. LV suboval in lateral view; RV more subrectangular. LV dorsal margin almost straight, short and slightly oblique; ventral margin slightly convex, but masked by the outline due to the median inflation of carapace. Anterior margin infracurvate in $\mathrm{LV}$, more equicurvate in $\mathrm{RV}$; posterior margin oblique in the upper part and forming median but short caudal process more truncate and with a spine in RV. Surface predominantly smooth. Ventrolateral region marked with feeble rib, almost invisible in its anterior part and becoming gradually thicker toward the posterior region, which holds a short and backwardly projected spine. Subparallel and below this rib, two or three few visible ribs. Regions adjacent to the cardinal angles marked with pits, the anterior one deeper than the posterior one. Normal porecanals few and sparse, more concentrated at the dorsal and posterodorsal margins. Internally, hinge amphidont, with anterior, median, and posterior elements well-defined. Anterior element composed of oblong small socket followed by bilobate tooth; median element composed of bar marked at the middle by short and shallow longitudinal sulcus; posterior socket long and faintly crenulated. Accommodation groove conspicuous along the middle element. Anterior duplicature fairly wide with line of concrescence and inner margin coincident, and with about 15 true (mostly branched) and three false radial porecanals. Posterior duplicature narrow with sparse radial porecanals, not properly observed in the specimens analyzed. AMS discrete but typical of the genus, composed of a row of four small adductor scars and a U-shaped frontal one placed slightly above the mid height. Ventral region marked with deep and well-developed sulcus analogous to the accommodation groove, where the ventral portion of the RV probably fits. Sexual dimorphism not observed.

Remarks. The LV of Pseudobosquetina pucketti sp. nov. is similar to the LV of the Cretaceous species Brachycythere sphenoides (Reuss 1854), illustrated by Jellinek et al. (2006, Figs. $1 \mathrm{G}$ and $1 \mathrm{H}$ ), but differs externally mainly in the obliquity of the dorsal margin and position and robustness of the ventrolateral rib. Pseudobosquetina pucketti sp. nov. resembles brachycytherine ostracods, mainly Brachycythere in several aspects, however, the adductor muscle scars are clearly different. Puckett (2002) argues that the median adductor scars of brachycytherine are subdivided, while in P. pucketti sp. nov. they are not. The hinge of $P$. pucketti sp. nov. is more robust than the specimens illustrated by Jellinek et al. (2006), and the radial pore canals are predominantly branched. Moreover, those species are larger and present feeble reticulation in some parts of carapace, contrasting with P. pucketti sp. nov, which is totally smooth. Finally, it is noteworthy the absence of a plication dorsal area in the LV of P. pucketti sp. nov.

\section{Family BYTHOCYTHERIDAE Sars 1866}

Bythoceratina Hornibrook 1953

Bythoceratina bonaterrae sp. nov.

(Figs. 3N-3Q)

2008 Bythocythere sp. Bergue and Coimbra, p. 117, pl. 2, figs. 10, 11 .

Etymology. L. In allusion to Boa Terra (=good land), an informal designation for the Bahia State, where the Camamu Basin lies.

Zoobank register. act:BA4727B3-5A20-4599-AA6B-375609705EAA.

Holotype. MP-O-2990, LV, L = $1.10 \mathrm{~mm} ; \mathrm{H}=0.65 \mathrm{~mm}$ (Sample $432 \mathrm{~cm}$, Pleistocene).

Paratypes. MP-O-2991, RV, L $=1.12 \mathrm{~mm} ; \mathrm{H}=0.60 \mathrm{~mm}$ (Sample $36 \mathrm{~cm}$, Holocene); MP-O-2992, LV, L = $1.08 \mathrm{~mm}$; H $=0.70 \mathrm{~mm}$ (Sample $456 \mathrm{~cm}$, Pleistocene); MP-O-2993, RV, $\mathrm{L}=1.03 \mathrm{~mm} ; \mathrm{H}=0.55 \mathrm{~mm}$ (Sample $450 \mathrm{~cm}$, Pleistocene).

Type-locality and horizon. Camamu Basin, core CMU 14 (14²4’S; 3849'12”W). Holocene.

Occurrence and abundance. MIS 5, 3, and 1. Samples: 12 $\mathrm{cm}(2 \mathrm{v}), 43 \mathrm{~cm}(2 \mathrm{v}), 199 \mathrm{~cm}(1 \mathrm{v}), 260 \mathrm{~cm}(1 \mathrm{v}), 322 \mathrm{~cm}(1 \mathrm{v})$, $335 \mathrm{~cm}(1 \mathrm{v}), 341 \mathrm{~cm}(3 \mathrm{v}), 395 \mathrm{~cm}(1 \mathrm{v}), 414 \mathrm{~cm}(3 \mathrm{v}), 432 \mathrm{~cm}$ (1v), $450 \mathrm{~cm}(1 \mathrm{v})$, and $456 \mathrm{~cm}(1 \mathrm{v})$.

Stratigraphical and geographical distribution. Pleistocene: Santos Basin (Brazil); Pleistocene-Holocene: Camamu Basin (Brazil); Recent: South Atlantic (Albatross Station 2760, $12^{\circ} 11^{\prime}$ 's $\left.37^{\circ} 28^{\prime} \mathrm{W}\right)$.

Diagnosis. A quite large species of Bythoceratina. Carapace predominantly smooth, but with numerous small normal porecanals. Anterior and posterior extremities of the bifurcated alae ornate with obtuse spines, some forked, and others simple, short, and robust.

Description. Carapace very large, subrectangular with outline strongly modified due to the well-developed alae. Anterior and posterior parts of the carapace flattened; the middle one inflated and with subtle and curved sulcus. Greatest length dorsally; greatest height and greatest width posteriorly. Dorsal margin almost 
straight but masked externally by longitudinal ridge resulting in false sinuosity in the anterior third. Ventral margin strongly sinuous, with conspicuous concavity in the oral region. Anterior margin slightly supracurvate with few delicate marginal spines whose number and position vary between the RV and the LV. Posterior margin supracurvate, marked by a short caudal process in line with hinge. Surface smooth, with numerous and small normal porecanals scattered throughout the carapace. A well-developed alae backwardly projected, subdivided and with a terminal spine at each extremity. Alae margin with many obtuse spines, some bifurcated, others simple, short, and robust. Internally, large duplicature as for the genus. Hinge merodont; anterior and posterior elements of LV composed by elongate sockets; median element a narrow crenulate grove. Central muscle scars and marginal porecanals not seen. Sexual dimorphism not observed.

Remarks. This quite large and smooth species of Bythoceratina shows many small and regularly scattered normal pore canals, and peculiar spines bordering the margin of the bifurcated alae, making it easy to distinguish it from the other species of the genus.

\section{DISCUSSION}

Paleoclimatic and paleobathymetric analyses in this paper are based on previously described ostracod species and in new species proposed herein, totaling 40 taxa (Figs. 2 and 3, Tab. 1). Only 19 of these species have been previously registered in the $\mathrm{BCM}$ or in the Rio Grande Rise. Data from the core CMU 14, therefore, indicate that bathyal ostracod assemblages from the northeast region of the BCM differ to some degree from the southeastern and southern ones. Additional studies, however, are necessary to test this hypothesis.

Occurrences along the CMU 14 reveal patterns at species and family level, not only of bathymetric preferences, but also their MIS occurrence. Considering that some of these species have been registered elsewhere along BCM, they constitute potential paleoclimatic indexes. An analogous pattern has been observed in other oceanic regions as, for instance, in the Arctic Ocean, where major climatic transitions in the mid-to-late

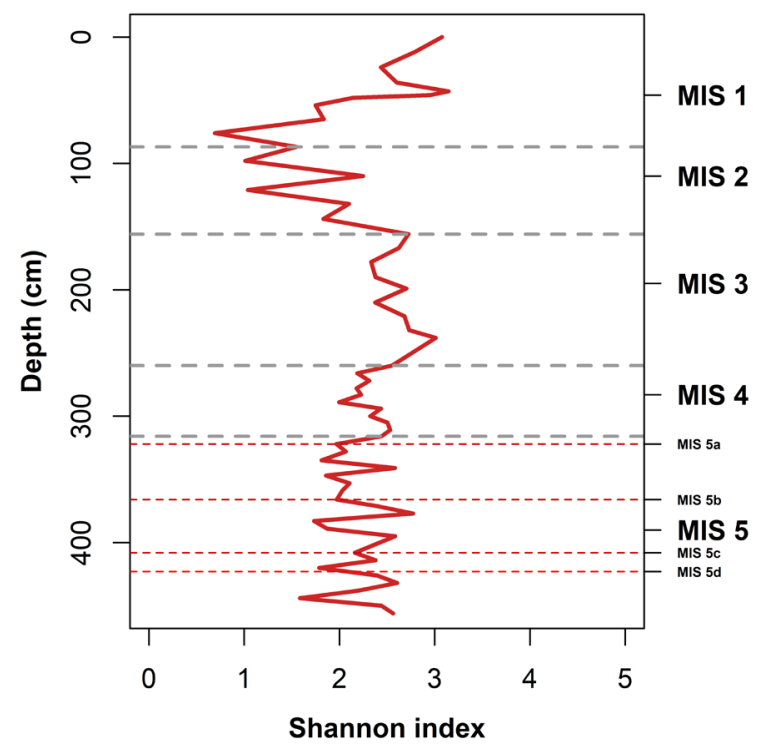

Figure 4. Shannon-Wiener diversity in CMU 14.
Quaternary are correlated to foraminifera and ostracods turnovers (Cronin et al. 2014). Bergue et al. (2017) discussed a possible correlation between the MIS and the occurrences of some ostracod species in bathyal regions off Brazil and southeast of the USA, based on the finding that Aversovalva tomcronini Bergue et al. 2016, Bythocypris kyamos Whatley et al. 1998 and Saida ionia are restricted to MIS 1. Occurrences of other species in the Campos Basin (Southeastern Brazilian Margin) also demonstrated paleoclimatic influence, particularly decreased diversity during MIS 2 (LGM) (Bergue et al. 2017).

In the core CMU 14 the most conspicuous pattern in terms of assemblage composition is also the decrease in abundance and diversity in MIS 2 (Fig. 4). Moreover, the occurrence of Bythocyprididae and Bythocytheridae is limited — with rare exceptions - to interglacial stages. Regarding Bythocyprididae (Fig. 5), Bythocypris affinis and Bythocypris sp. occur only in MIS 1, while Zabythocypris sp. occurs in MIS 5, 3 (rare), and 1. The Bythocytheridae species (Fig. 6) show pattern similar to Bythocyprididae except for the single occurrence of

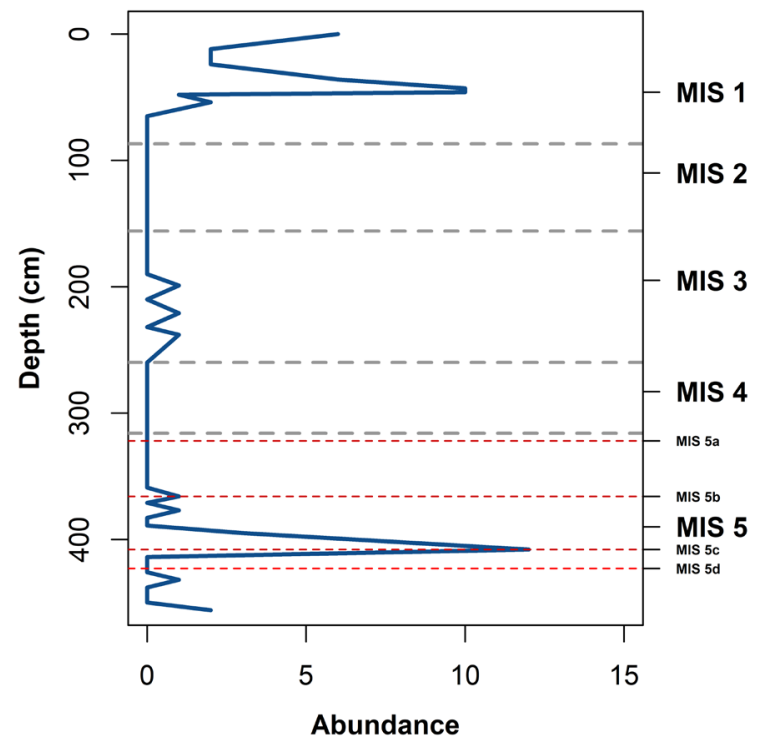

Figure 5. Total abundance of Bythocyprididae along the core CMU 14.

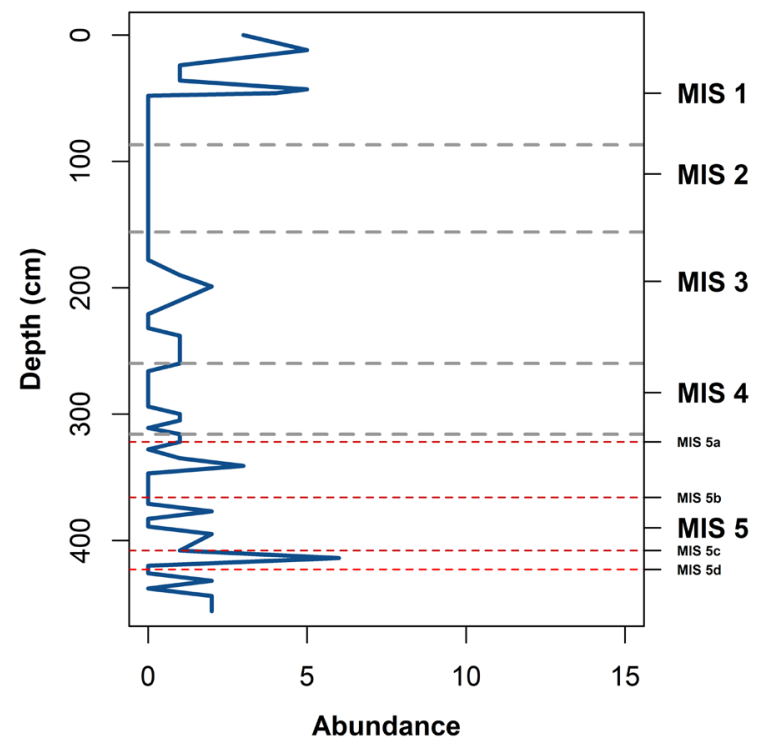

Figure 6. Total abundance of Bythocytheridae along the core CMU 14. 
Bythoceratina sp. in MIS $4(300 \mathrm{~cm})$. Other species are also restricted to interglacial stages along the core CMU 14, such as Ambocythere circumporus, Bradleya dictyon (Brady 1880), Cytherella pindoramensis sp. nov., Cytheropteron perlaria and Cytheropteron inornatum Brady and Robertson 1872.

On the other hand, a few taxa (e.g. Rugocythereis horrida (Whatley and Coles 1987) and Macrosarisa bensoni Maddocks 1990 occur continuously throughout the core. Ostracods species with continual occurrence are not uncommon in the fossil record as demonstrated by Bradleya majorani Bergue et al. 2019, in the Rio Grande Rise and Paracypris polita Sars 1866 in the Mediterranean (Pirkenseer et al. 2018). Probably, taxa with continual occurrence are physiologically less influenced by the OMZ and thermocline depth changes, that triggers upslope/downslope migrations (Rodriguez-Lazaro and Cronin 1999). In the core CMU 14, however, the changes

Table 1. Species registered in the core CMU 14 and in other bathyal regions in the BCM and respective marine isotope stage.

\begin{tabular}{|c|c|c|c|c|}
\hline Species & ${ }^{(a, b)}$ Pelotas & (c)Santos & ${ }^{(\mathrm{d}, \mathrm{e})}$ Campos & ${ }^{(\mathrm{f})}$ Camamu \\
\hline Ambocythere amadoi sp. nov. & & & & $5-2$ \\
\hline Ambocythere circumporus & & 1 & 3,1 & 5,3 \\
\hline Argilloecia acuminata & & & 2,1 & $5-1$ \\
\hline Argilloecia labri & & & 3 & 5,3 \\
\hline Aversovalva hydrodynamica & & 2,1 & 2,1 & $5,2,1$ \\
\hline Bairdia sp. aff. B. hirsuta & & 1 & & $5-1$ \\
\hline Bradleya dictyon & & & & 5,1 \\
\hline Bythoceratina bonaterrae sp. nov. & & Ple & & $5,3,1$ \\
\hline Bythoceratina scaberrima & & & & $5,4,1$ \\
\hline Bythoceratina sp. & 1 & 1 & 2,1 & 1 \\
\hline Bythocypris sp. & 1 & 1 & 1 & \\
\hline Bythocypris affinis & & & 1 & 1 \\
\hline Bythocythere eugeneschornikovi & & & & 5,1 \\
\hline Bythopussela brandtae & & & & 3 \\
\hline Cardobardia bensoni & & & & $5-1$ \\
\hline Cytherella santosensis & & Ple & & 5,4 \\
\hline Cytherella pindoramensis & & & & $5,3,1$ \\
\hline Cytheropteron carolinae & & & & 1 \\
\hline Cytheropteron demenocali & & & & 3,1 \\
\hline Cytheropteron inornatum & & & & $5,3,1$ \\
\hline Cytheropteron lineoporosa & & & & 3,1 \\
\hline Cytheropteron massoni & & & & 3 \\
\hline Cytheropteron perlaria & 1 & $\mathrm{Ple} / 1$ & 1 & $5-1$ \\
\hline Cytheropteron pherozigzag & & & & 5,3 \\
\hline Eucythere circumcostata & & & & 1 \\
\hline Eucytherura sp. cf. E. calabra & & 2,1 & & $3-1$ \\
\hline Jonesia cuneata & & Ple & & 3,1 \\
\hline Macropyxis alanlordi & & & & 5 \\
\hline Macropyxis cronini & & & & $5,2,1$ \\
\hline Macrosarisa bensoni & & & & $5-1$ \\
\hline Marwickcythereis ericea & & & 2 & $5-1$ \\
\hline Microcythere dubia & & 2,1 & & 3 \\
\hline Microcythere acuminata & & & & 2 \\
\hline Paracytherois antarctica & & & & $5,3-1$ \\
\hline Pedicythere lachesisopetasi & & 2,1 & & $5-3,1$ \\
\hline Pseudobosquetina pucketti & & & & 5,3 \\
\hline Rugocythereis horrida & & & & $5-1$ \\
\hline Saida ionia & 1 & 1 & 1 & 3,1 \\
\hline Xylocythere turnerae & & & & $5-3,1$ \\
\hline Zabythocypris sp. & & & & $5,3,1$ \\
\hline
\end{tabular}

(A) Bergue et al. (2016); (B) Maia et al. (2021); (C) Bergue and Coimbra (2008); (D) Sousa et al. (2013); (E) Bergue et al. (2017); (F) this study; Ple: Pleistocene. 
observed in assemblages composition are probably related to productivity instead because the core site is below the thermocline. Therefore, the appearance/disappearance of species along the core CMU 14 are neither attributed to hydrological changes nor to speciation/extinction, but to productivity variations climatically induced as observed by Cronin et al. (1999) and Yasuhara et al. (2009b).

Comparison of CMU 14 data to previous studies in the BCM (Tab. 1) also reveals three bathymetric intervals of occurrence: an outer neritic/upper bathyal ( $400 \mathrm{~m}$ water depth); a middle bathyal (400-1,000 m water depth); and a lower bathyal (below 1,000 $\mathrm{m}$ water depth). The taxonomic composition of the assemblages in these intervals might vary from basin to basin, but in general they share some characteristics as described below.

\section{Outer neritic/upper bathyal assemblages}

Composed of species which inhabit both the outer shelf and the upper part of the slope. These asemblages are particularly prone to be influenced by changes in the thermocline depth, and most of their species have limited geographic occurrence. Examples: Aversovalva tomcronini, Bradleya gaucha Bergue et al.2016, Cytherella pleistocenica Bergue et al. 2007, Eucythere macerata Bergue and Coimbra 2008, Krithe coimbrai Do Carmo and Sanguinetti 1999, and Krithe gnoma Do Carmo and Sanguinetti 1999.

\section{Middle bathyal assemblages}

These assemblages have a high incidence of psychrospheric taxa such as bythocytherids, bythocypridids, and some krithids. Some species present broad geographic occurrence. Examples: Apatihowella acelos Bergue et al. 2016, Apatihowella besnardi Bergue et al. 2016, Bythoceratina scaberrima, Cytheropteron perlaria, Legitimocythere aorata Bergue and Coimbra 2008, and Saida ionia.

\section{Lower bathyal assemblages}

Species registered in the BCM exclusively below the 1,000 $\mathrm{m}$ isobath. Many have pandemic distribution. The most characteristic component of this fauna is Poseidonamicus Benson 1972 (Bergue and Coimbra 2008, Bergue et al. 2017, Maia et al. 2021, and other unplublished data), which constitutes a reliable hydrological marker. Examples: Cytherella santosensis, Krithe trinidadensis van den Bold 1958, Krithe morkhoveni van den Bold 1960, Jonesia cuneata, Poseidonamicus hisayoae Yasuhara et al.2009a, and Poseidonamicus pintoi Benson 1972.

\section{CONCLUSIONS}

- Assemblages of the core CMU 14 (northeastern margin) show some differences in composition when compared to the southern Brazilian margin ones (i.e. Pelotas, Santos, and Campos), possibly due to ecological particularities linked to the slope morphology, which influenced locally ostracod faunas during the last $108 \mathrm{kyr}$;

- Bythocytheridae and Bythocyprididae of the present study have a climatically induced pattern of occurrence, as evidenced by their remarkable records during the interglacial MIS, and are possibly paleoceanographical markers;

- Podocopid richness diminished during the LGM (MIS 2) but no faunal turnover is observed, because all species occurring after the LGM are also present before it, except Bythocypris affinis and Bythocypris sp.;

- The association Bythocypris affinis-Cytherella pindoramensis sp. nov.- Cytheropteron perlaria-Bradleya dictyon characterize MIS 5 and 1 (interglacials). Glacial stages do not present typical associations, but as a rule they show lower diversity;

- The data from the CMU 14 reinforce the possibility of an ostracod-based climatic zoning for the $\mathrm{BCM}$ as preliminarily proposed by Bergue et al. (2017)

\section{ACKNOWLEDGMENTS}

This paper is part of a project supported by both the IODPCAPES (grant 88887.091727/2014-1) and the National Council for Scientific and Technological Development (CNPq) (grant 305128/2017-5). Picking and slides preparation were carefully carried out by Demétrio Dias Nicolaidis. Anderson Martins is thanked for SEM work and Terry Markham Puckett by invaluable discussion and bibliographic supply. Simone Nunes Brandão and an anonymous reviewer are thanked for their careful review and comments.

\section{ARTICLE INFORMATION}

Manuscript ID: 20210039. Received on: 05/24/2021. Approved on: 08/03/2021.

C.T.B. wrote the first draft, provided species identification and description of new species, prepared figures 1, 2, and 3; M.N.R. improved the manuscript, made diversity analysis, and figures 4, 5, and 6; J.C.C. improved the manuscript and contributed to the description of new species; K.B.C. dated the samples and contributed to the paleoecological interpretation. Competing interests: The authors declare no competing interests.

\section{REFERENCES}

Ayress M.A., De Deckker P., Coles G.P. 2004. A taxonomic and distributional survey of marine benthonic Ostracoda off Kerguelen and Heard Islands, South Indian Ocean. Journal of Micropalaeontology, 23(1):15-38. https:// doi.org/10.1144/jm.23.1.15
Bard E. 1988. Correction of accelerator mass spectrometry ${ }^{14} \mathrm{C}$ ages measured in planktonic foraminifera: paleoceanographic implications. Paleoceanography and Paleoclimatology, 3(6):635-645. https://doi. org/10.1029/PA003i006p00635 
Benson R.H. 1972. The Bradleya problem, with descriptions of two new psychrospheric ostracode genera, Agrenocythere and Poseidonamicus (Ostracoda: Crustacea). Smithsonian Contributions to Paleobiology, 12:1138. https://doi.org/10.5479/si.00810266.12.1

Benson R.H. 1975. The origin of the psychrosphere as recorded in changes of deep-sea ostracode assemblages. Lethaia, 8(1):69-83. https://doi. org/10.1111/j.1502-3931.1975.tb00919.x

Benson R.H., Chapman R.E., Deck L.T. 1984. Paleoceanographic events and deep-sea ostracodes. Science, 224(4655):1334-1336. https://doi. org/10.1126/science.224.4655.1334

Bergue C.T., Brandão S.N., Zerfass G.S. 2019. Palaeoceanographic events from the Late Miocene to the Pleistocene of the Rio Grande Rise (Southwestern Atlantic) as indicated by Ostracoda. Journal of Systematic Palaeontology, 17(17):1277-1298. https://doi.org/10.1080/14772019.20 18.1536895

Bergue C.T., Coimbra J.C. 2008. Late Pleistocene and Holocene bathyal ostracodes from the Santos Basin, southeastern Brazil. Palaeontographica Abteilung A, 285:101-144. https://doi.org/10.1127/pala/285/2008/101

Bergue C.T., Coimbra J.C., Cronin T.M. 2007. Cytherellid species (Ostracoda) and their significance to the late Quaternary events in the Santos Basin, Brazil. - Senckenbergiana Maritima, 37:5-12. https://doi. org/10.1007/BF03043205

Bergue C.T., Coimbra J.C., Pivel M.A.G., Petró S.M., Mizusaki A.M.P. 2017. Taxonomy and climatic zonation of the Late Quaternary bathyal ostracods from the Campos Basin. Revue de Micropaléontologie, 60(4):493-509. https://doi.org/10.1016/j.revmic.2017.07.001

Bergue C.T., Coimbra J.C., Ramos M.I.F. 2016. Taxonomy and bathymetric distribution of the outer neritic/upper bathyal ostracodes (Crustacea: Ostracoda) from the southernmost Brazilian continental margin. Zootaxa, 4079(1):65-86. https://doi.org/10.11646/zootaxa.4079.1.5

Bergue C.T., Costa K.B., Dwyer G., Moura C.A.V. 2006. Bathyal ostracode diversity in the Santos Basin, Brazilian southeast margin: response to Late Quaternary climate changes. Revista Brasileira de Paleontologia, 9(2):201210. https://doi.org/10.4072/rbp.2006.2.04

Brady G.S. 1866. On new or imperfectly known species of marine Ostracoda. The Transactions of the Zoological Society of London, 5(5):359-393. https:// doi.org/10.1111/j.1096-3642.1866.tb00649.x

Brady G.S. 1880. The Voyage of HMS Challenger. Zoology. Report on the Ostracoda dredged by HMS during the years 1873-1876. p. 1-184.

Brady G.S. 1886. Les ostracodes nouveaux des explorations du travailleur et du Talisman. Les Fonds de la Mer, 4:164-200.

Brady G.S., Robertson D. 1872. Contributions to the study of the Entomostraca. No. 6. On the distribution of the British Ostracoda. Annals and Magazine of Natural History, 9(49):48-70. https://doi. org/10.1080/002229372011951774

Brandão S.N. 2008. New species of Bairdioidea from the Southern Ocean and discussions on Bairdoppilata simplex (Brady, 1880), ?Bairdoppilata labiata (Müller, 1908) and Bythopussela aculeata (Müller, 1908). Zootaxa, 1866:373-452.

Brandão S.N. 2010. Macrocyprididae (Ostracoda) from the Southern Ocean: taxonomic revision, macroecological patterns, and biogeographical implications. Zoological Journal of the Linnean Society, 159(3):567-672. https://doi.org/10.1111/j.1096-3642.2009.00624.x

Caixeta J.M., Milhomen P.S., Witzke R.E., Depuy I.S.S., Gontijo G.A. 2007. Bacia de Camamu. Boletim de Geociências da Petrobras, 15:455-461.

Carreño A.L., Coimbra J.C., Carmo D.A. 1999. Late Cenozoic sea level changes evidenced by ostracodes in the Pelotas Basin, southernmost Brazil. Marine Micropaleontology, 37(2):117-129. https://doi.org/10.1016/ S0377-8398(99)00014-6

Ciampo G. 1988. Nuove specie di ostracodi pliocenici dela Callabria ionica. Bolletino della Società Paleontologica Italiana, 27:307-321.

Colalongo M.L., Pasini G. 1980. La ostracofauna plio-pleistocenica della Sezione Vrica in Calabria (con considerazioni sul limite Neogene/ Quaternario). Bolletino della Società Paleontologica Italiana, 19:44-126.

Cronin T.M. 1983. Bathyal ostracodes from the Florida-Hatteras slope, the Straits of Florida, and the Blake Plateau. Marine Micropaleontology, 8(2):89119. https://doi.org/10.1016/0377-8398(83)90007-5
Cronin T.M., DeMartino D.M., Dwyer G.S., Rodriguez-Lazaro J. 1999. Deep-sea ostracode species diversity: response to late Quaternary climate change. Marine Micropaleontology, 37(3-4):231-249. https://doi. org/10.1016/S0377-8398(99)00026-2

Cronin T.M., DeNinno L.H., Polyak L., Caverly E.K., Poore R.Z., Brenner A., Rodriguez-Lazaro J., Marzen R.E. 2014. Quaternary ostracode and foraminiferal biostratigraphy and paleoceanography in the western Artic Ocean. Marine Micropaleontology, 111:118-133. https://doi.org/10.1016/j. marmicro.2014.05.001

Cronin T.M., Dwyer G.S. 2003. Deep sea ostracodes and climate change. Pp. 247-263. In: Park L.E., Smith A.J. (eds.). Bridging the gap: Trends in the ostracode biological and geological sciences. The Paleontological Society Papers, 9. New Haven: The Paleontological Society. p. 247-263.

Do Carmo D.A., Sanguinetti Y.T. 1999. Taxonomy and palaeoceanographical significance of the genus Krithe (Ostracoda) in the Brazilian margin. Journal of Micropalaeontology, 18:111-123. https://doi. org/10.1144/jm.18.2.111

Drozinski N.G.S., Coimbra J.C., Carreño A.L., Bergue C.T. 2003. Ostracoda cool water masses indicators from the Rio Grande do Sul state, Brazil - a first approcah. Revista Brasileira de Paleontologia, 5:59-71.

Hao Y.C. 1988. Systematic description of microfossils. 2. Ostracoda. In: Ruan P.H., Hao Y.C. (eds.). Quaternary microbiotas in the Okinawa trough and their geological significance. Beijing: Geological Publishing House, p. 227-395.

Hartmann G. 1992. Antarktische benthische Ostracoden. VIII. Auswertung der Reise der "Meteor" (Ant. 11/4) in die Gewässer um Elephant Island und der Antarktischen Halbinsel. Helgoländer Meeresuntersuchungen, 46(4):405-424.

Jellinek T., Swanson K.M., Mazzini I. 2006. Is the cosmopolitanism still valid for deep-sea podocopid ostracods. Senckenbergiana Maritima, 36:2950. https://doi.org/10.1007/BF03043701

Liebau A. 2005. A revised classification of the higher taxa of the Ostracoda (Crustacea). Hydrobiologia, 538:115-137. https://doi.org/10.1007/ PL00021865

Maddocks R.F. 1972. Two new living species of Saipanetta (Ostracoda, Podocopida). Crustaceana, 23(1):28-42.

Maddocks R.F. 1990. Living and Fossil Macrocyprididae (Ostracoda). The University of Kansas Paleontological Contributions. Monograph 2. Lawrence: The University of Kansas Paleontological Institute, $404 \mathrm{p}$.

Maddocks R.F., Steineck P. 1987. Ostracoda from experimental woodisland habitats in the deep-sea. Micropaleontology, 33(4):318-355. https:// doi.org/10.2307/1485572

Maia R.J.A., Piovesan E.K., Bergue C.T., Zerfass G.S., Melo R. 2021. Bathyal Ostracods from the Upper Pleistocene of the Rio Grande Cone, Pelotas Basin, Brazil. Revue de Micropaleontologie, 71, 100483 https://doi. org/10.1016/j.revmic.2021.100483

Majoran S., Dingle R.V. 2002. Faunal changes in Cenozoic deep-sea ostracod assemblages from the South Atlantic and the Southern Ocean and their palaeoceanographical implications. GFF, 124(1):19-26. https://doi. org/10.1080/11035890201241019

Manica R.M., Bergue C.T., Coimbra J.C. 2015. The Lower Miocene Cytherellids (Crustacea, Ostracoda) from the Pelotas Basin and their significance for the South Atlantic Paleozoogeography. Revista Brasileira de Paleontologia, 18(2):217-224. https://doi.org/10.4072/rbp.2015.2.03

Martins L.R., Coutinho P.N. 1981. The Brazilian continental margin. Earth-Science Reviews, 17(1-2):87-107. https://doi. org/10.1016/0012-8252(81)90007-6

Müller G.W. 1894. Die Ostracoden des Golfes von Neapel und der angrenzenden Meeresabschnitte. In: Naples Stazione Zoologica. Fauna und Flora Golfes von Neapel, Monographie. Leipzig: Verlag Von Wilhelm Engelmann, v. 31, p. 1-104.

Pirkenseer C.M., Spezzaferri S., Stalder C. 2018. Late glacial and Holocene Ostracoda frm the Melilla cold-water coral mound field. Swiss Journal of Geosciences, 111:549-560. https://doi.org/10.1007/ s00015-018-0305-8

Puckett T.M. 2002. Systematics and paleobiogeography of brachycytherine Ostracoda. Micropaleontology, 48(2):1-87. 
Reuss A.E. 1854. Beitriige zur Charakteristik der Kreideschichten in den Ostalpen, besonders ira Gosauthale und am Wolfgangsee. Wien: Aus der Kaiserlich-Königlichen Hof- und Staatsdruckerei, v. 7, p. 1-156.

Rodriguez-Lazaro J., Cronin T.M. 1999. Quaternary glacial and deglacial Ostracoda in the thermocline of the Little Bahama bank (NW Atlantic): palaeoceanographic implications. Palaeogeography, Palaeoclimatology, Palaeoecology, 152(3-4):339-364. https://doi.org/10.1016/ S0031-0182(99)00048-6

Sars G.O. 1866. Oversigt af Norges marine Ostracoder. Förhandlinger I Videnskabs-Selskabet $i$ Christiania, 7(1):1-130.

Schornikhov E.I. 1981. Bythocytheridae ostracods from the far eastern seas. Moscow: Nauka, $200 \mathrm{p}$.

Shannon C.E. 1948. A mathematical theory of communication. Bell System Technical Journal, 27(3):379-423. https://doi. org/10.1002/j.1538-7305.1948.tb01338.x

Sousa A.J., Queiroz Neto J.V., Ferreira E.P. 2013. Evidências de transporte de sedimentos no Quaternário do talude inferior da Bacia de Campos com base em ostracodes alóctones. Boletim de Geociências da Petrobras, 21:85-102.

Stramma L., England M. 1999. On the water masses and mean circulation of the South Atlantic Ocean. Journal of Geophysical Research, 104(C9):2086320883. https://doi.org/10.1029/1999JC900139

Swanson K.M., Jellinek T., Malz H. 2005. The platycopine condition: new observations on reproduction, respiration and feeding in living, deep-sea Platycopina (Crustacea, Ostracoda). Senckenbergiana Maritima, 35:157187. https://doi.org/10.1007/BF03043684

Toledo F.A.L., Costa K.B., Pivel M.A.G. 2007. Salinity changes in the western tropical South Atlantic during the last $30 \mathrm{kyr}$. Global and Planetary Change, 57(3-4):383-395. https://doi.org/10.1016/j.gloplacha.2007.01.001

van den Bold W.A. 1957. Ambocythere, a new genus of Ostracoda. Annals and Magazine of Natural History, 10:801-813.

van den Bold W.A. 1958. Ostracoda of the Brasso Formation of Trinidad. Micropaleontology, 4(4):391-418.

van den Bold W.A. 1960. Eocene and Oligocene Ostracoda of Trinidad. Micropaleontology, 6(2):145-196.

van den Bold W.A. 1974. Taxonomic status of Cardobairdia (van den Bold, 1960) and Abyssocypris n. gen., two deepwater ostracode genera of the Caribbean Tertiary. Geoscience and Man, 6:65-79.
Whatley R.C., Ayress M., Downing S. 1986. Two unusual new species of the ostracod genus Cytheropteron from the Late Cenozoic of the deep sea. Journal of Micropaleontology, 5 (6):31-36. https://doi.org/10.1144/jm.5.1.31

Whatley R.C., Coles G. 1987. The Late Miocene to Quaternary Ostracoda of Leg 94, Deep Sea Drilling Project. Revista Española de Micropaleontología, 19(1):33-97.

Whatley R.C., Coles G. P. 1991. Global change and the biostratigraphy of North Atlantic Cainozoic deep water Ostracoda. Journal of Micropalaeontology, 9:119-132. https://doi.org/10.1144/jm.9.2.119

Whatley R.C., Moguilevsky A., Chadwick J., Toy N., Ramos M.I.F. 1998. Ostracoda from the South West Atlantic. Part III. The Argentinean, Uruguayan and southern Brazilian continental shelf. Revista Española de Micropaleontología, 30:86-116.

Yasuhara M., Cronin T.M. 2008. Climatic influences on deep-sea ostracodes (Crustacea) diversity for the last three million years. Ecology, 89(11 Suppl.):S53-65. https://doi.org/10.1890/07-1021.1

Yasuhara M., Cronin T.M., Hunt G., Hodell D.A. 2009a. Deep-sea ostracods from the South Atlantic sector of the Southern Ocean during the last 370,000 years. Journal of Paleontology, 83(6):914-930. http://doi. org/10.1666/08-149.1

Yasuhara M., Hunt G., Cronin T.M., Okahashi H. 2009b. Temporal latitudinal-gradient dynamics and tropical instability of deep-sea species diversity. PNAS, 106(51):21717-21720. https://doi.org/10.1073/ pnas.0910935106

Yasuhara M., Hunt G., Okahashi H., Brandão S.N. 2015. Taxonomy of deepsea Trachyleberidid, Thaerocytherid and hemicytherid genera (Ostracoda). Smithsonian Contributions to Paleobiology, 96:1-216. http://dx.doi. org/10.5479/si.1943-6688.96

Yasuhara M., Okahashi, H. 2015. Late Quaternary deep-sea ostracod taxonomy of the eastern North Atlantic. Journal of Micropalaeontology, 34:21-49. https://doi.org/10.1144/jmpaleo2013-022

Yasuhara M., Okahashi H., Cronin T.M. 2009c. Taxonomy of Quaternary deep-sea ostracods from the western North Atlantic Ocean. Palaeontology, 52:879-931. http://doi.org/10.1111/j.1475-4983.2009.00888.x

Yasuhara M., Okahashi H., Cronin T.M., Rasmussen T. L., Hunt G. 2014. Response of deep-sea biodiversity to abrupt deglacial and Holocene climate changes in the North Atlantic Ocean. Global Ecology and Biogeography, 23(9):957-967. https://doi.org/10.1111/geb.12178 